\title{
Intact Forest in Selective Logging Landscapes in the Tropics
}

\author{
Francis E. Putz ${ }^{1 *}$, Tracy Baker ${ }^{2}$, Bronson W. Griscom ${ }^{3}$, Trisha Gopalakrishna ${ }^{3}$, \\ Anand Roopsind ${ }^{4}$, Peter M. Umunay ${ }^{5}$, Joey Zalman ${ }^{6}$, Edward A. Ellis ${ }^{7}$, Ruslandi ${ }^{8}$ and \\ Peter W. Ellis ${ }^{3}$

\begin{abstract}
${ }^{1}$ Department of Biology, University of Florida, Gainesville, FL, United States, ${ }^{2}$ The Nature Conservancy - Africa Region, Highland, NY, United States, ${ }^{3}$ The Nature Conservancy, Arlington, VA, United States, ${ }^{4}$ Department of Biological Sciences, Boise State University, Boise, ID, United States, ${ }^{5}$ Yale School of Forestry \& Environmental Studies, New Haven, CT, United States, ${ }^{6}$ Foundation for Forest Management and Production Control, Paramaribo, Suriname, ${ }^{7}$ Centro de Investigaciones Tropicales Universidad Veracruzana, Xalapa, Mexico, ${ }^{8}$ The Nature Conservancy International Program, Jakarta, Indonesia
\end{abstract}

The selective logging that characterizes most timber extraction operations in the tropics leaves large patches of logging blocks (i.e., areas allocated for harvesting) intact, without evidence of direct impacts. For example, in $\sim 10,000$ ha sampled in 48 forest management enterprises in Africa (Gabon, Republic of Congo, and the Democratic

OPEN ACCESS

Edited by:

Alexandra C. Morel,

University of Oxford, United Kingdom

Reviewed by:

Bradley Christoffersen,

University of Texas Rio Grande Valley,

United States

David Gorchov,

Miami University, United States

*Correspondence:

Francis E. Putz

fep@ufl.edu

Specialty section:

This article was submitted to

Tropical Forests,

a section of the journal

Frontiers in Forests and Global

Change

Received: 11 January 2019

Accepted: 23 May 2019

Published: 12 June 2019

Citation:

Putz FE, Baker T, Griscom BW,

Gopalakrishna T, Roopsind A,

Umunay PM, Zalman J, Ellis EA,

Ruslandi and Ellis PW (2019) Intact

Forest in Selective Logging

Landscapes in the Tropics.

Front. For. Glob. Change 2:30.

doi: $10.3389 / f f g c .2019 .00030$
Republic of Congo), Indonesia, Suriname, and Mexico, an average of 69\% (range 2097\%) of the area in logging blocks was not directly affected by timber harvests. The proportion of intact forest within logging blocks decreased very slightly with increases in harvest intensity in the accessed portion of the logging blocks (9-86 $\left.\mathrm{m}^{3} \mathrm{ha}^{-1}\right)$ but decreased strongly with harvest intensity in entire logging blocks $\left(0.3-48.2 \mathrm{~m}^{3} \mathrm{ha}^{-1}\right)$. More forest was left intact in areas farther from roads, on slopes $>40 \%$, and within $25 \mathrm{~m}$ of perennial streams, but the effect sizes of each of these variables was small ( 8\%). It is less clear how much of the intact forest left after one harvest will remain intact through the next. Conservation benefits without reductions in timber yields will derive from better management planning so that sensitive and ecologically critical areas, such as steep slopes and riparian buffers, constitute large and permanent proportions of the intact forest in selectively logged landscapes in the tropics.

Keywords: conservation, land-use planning, reduced-impact logging, sparing-sharing, tropical forestry

\section{INTRODUCTION}

Heightened concerns about tropical forest fates and limited funds for their conservation are reasons to strive for efficiency and effectiveness in investments in environmental protection. Where forests are threatened by agricultural conversion, insights have been derived from contrasts of the ends of the land-use continuum that runs from forest sparing via agricultural intensification in small areas through land-sharing with extensive wildlife-friendly agricultural practices (e.g., Phalan et al., 2011). This dichotomous approach proved less appropriate where productive land uses do not result in biodiversity decimation, such as natural forest management based on selective logging (e.g., Edwards et al., 2014; Griscom et al., 2018; Runting et al., 2019). Here we elaborate on the forest sparing-sharing discourse by focusing on forest spared from logging's direct impacts in landscapes allocated for timber production. By direct impacts, we mean logging-induced changes in vegetation and soils such as forest clearing and soil scarification for road building, 
soil compaction on skid trails, and canopy opening in felling gaps. We refer to these spared stands as "intact" in full recognition that they may have lost or might soon lose their fauna, may be hydrologically compromised, or suffer other forms of degradation such as from pollution and invasive exotic species. In other words, we focus only on the direct or primary impacts of selective logging in full recognition of the often critical secondary impacts associated with the access provided by logging roads.

Due to differences in market acceptability and commercial species stocking, logging intensities also vary substantially among regions (e.g., Putz et al., 2001; Ellis P. W. et al., 2019). For example, in the forest management enterprises (FMEs) analyzed in this study, logging intensities ranged from 0.3 and $1.1 \mathrm{~m}^{3}$ $\mathrm{ha}^{-1}$ in two Mexican ejidos (i.e., community-based FMEs; Ellis E. A. et al., 2019) to 53.3 and $56.5 \mathrm{~m}^{3} \mathrm{ha}^{-1}$ in two industrial concessions in Indonesia (Griscom et al., 2019). Understanding how the intensity of timber trees removal affects the intactness of forest within a logging block is critical for future management planning.

Due to the spatial aggregation of commercially valuable timber trees in most tropical forests, coupled with topographical impediments and other biophysical/economic constraints, selective logging is notoriously patchy. This aggregation means that values for intensity that are averaged over large areas often poorly reflect conditions on the ground. For example, in 32 plots of 1 ha set up prior to logging in East Kalimantan, Indonesia, (Sist et al., 1998) reported that logging intensities averaged $86.9 \mathrm{~m}^{3} \mathrm{ha}^{-1}$ (nine trees ha ${ }^{-1}$ ) but ranged 9-247 $\mathrm{m}^{3} \mathrm{ha}^{-1}$ with 1-17 trees $\mathrm{ha}^{-1}$ harvested. In Gabon, where overall logging intensities averaged $8.11 \mathrm{~m}^{3} \mathrm{ha}^{-1}$ and 0.82 trees $\mathrm{ha}^{-1}$, five of the ten 1 ha plots established in the logging area yielded no timber, and two of those were also not traversed by skid trails (Medjibe et al., 2011). Reported levels of spatial variance are noticeably lower in studies in which plots were set up postlogging to represent a range of logging intensities (e.g., Ewers and Banks-Leite, 2013; Riutta et al., 2018), but can nevertheless be substantial, especially when sampled at sub-hectare scales (e.g., Pfeifer et al., 2016; Senior et al., 2017).

In discussions of intactness, the issues of spatial scale and characteristics of surrounding habitats should loom large. We fully endorse appropriate forms of protection for as much of the remaining large swaths of intact tropical forests as possible; those areas are of irreplaceable environmental and spiritual value. Smaller areas of forest might not support viable populations of forest interior species and may not provide people with wilderness experiences. Nevertheless, even small patches of undisturbed forest are functionally intact for some processes and fully suitable for some species while they maintain gene pools and serve as seed sources (e.g., Turner and Corlett, 1996; Arroyo-Rodríguez et al., 2009). Furthermore, the ecological value of small intact areas is augmented if the surroundings are selectively logged and not cleared, especially if the harvests are low intensity and conducted using reduced-impact (RIL) logging practices. In regards to the permanence of the status of intact patches of forest in selectively logged landscapes, we argue that even temporary reprieves from deforestation or degradation are of value, given the rate of wholesale forest destruction. An analogous situation pertains to "wildfire refugia," those patches of unburned forest in landscapes subjected to mixed-severity fires (e.g., Kolden et al., 2017).

Although the shape and temporal permanence of intact forest patches in logged landscapes are not considered in our analysis, we recognize that intactness is as multidimensional a concept as forest degradation (e.g., Thompson et al., 2013) and similarly deserving of local definitions (e.g., Vásquez-Grandon et al., 2018). What makes defining intactness particularly challenging is that its dimensions are not all orthogonal, linear, continuous, and constant, nor can they all be objectively delineated. Proclaimed definitions or benchmarks (e.g., $>500 \mathrm{~km}^{2}$; Potapov et al., 2017) are easily communicated and can be politically expedient, but the fact remains that intactness is not a binary trait. We argue that intact forest in logged landscapes ranges in size from small and isolated patches of remnant trees through contiguous strips of riparian forest, to unlogged high-conservation value areas of hundreds or thousands of hectares.

Here we describe the spatial heterogeneity of selective logging impacts in tropical Southeast Asia, Africa, and the Americas with field data collected with identical protocols and analyzed in a uniform manner. We explore why intact forest was retained in logged landscapes such as due to regulatory constraints (e.g., riparian buffer zones), remoteness, steepness, low soil trafficability, inaccessibility (e.g., surrounded by rocky cliffs), or low stocking. This last-mentioned condition may be permanent, if due to adverse conditions, or temporary. With some reluctance because this study was not designed to assess the impacts of Forest Stewardship Council (FSC) certification [for a description of how such studies should be designed see (Romero et al., 2017)], we also present a naïve comparison of the proportions of logged blocks left intact in the 12 certified FMEs with the 36 non-FSC FMEs. We note that a similar analysis for the same FMEs revealed no association between FSC certification and carbon emissions from selective logging (Ellis P. W. et al., 2019).

\section{CAVEAT}

Before proceeding, we want to clarify that we are not unquestioning advocates of logging, especially not in primary forest. Nevertheless, we accept that tropical forests will continue to be logged and recognize the geopolitical and economic justifications for use of renewable natural resources. This justification is bolstered by the failure of environmentalists to secure the funds needed to make protection a financially attractive option for all but a few forests. Our main goal is improved timber stand management, as appropriate for maintenance of ecological integrity, in tropical forests that will be logged. We also assert that intact forest within logging landscapes deserve recognition and that there are environmental as well as economic benefits to be derived from better spatial planning of tropical forest management. That said, we do not equate relatively small patches of unlogged forest in selectively logged landscapes with the extensive (i.e., $>500 \mathrm{~km}^{2}$ ) areas free from substantial human impacts that qualify as "Intact Forest Landscapes," as 
defined by Potapov et al. (2008) and mapped and tracked by international organizations including such as World Resources Institute and Greenpeace (http://www.intactforests.org/; Potapov et al., 2017). We point out, however, that selectively logged landscapes maintain substantial proportions of their biodiversity and carbon stocks (e.g., Sist and Nguyen-Thé, 2002; Putz et al., 2012; Edwards et al., 2014), especially if logging intensities are low (i.e., $<8$ trees $\mathrm{ha}^{-1}$; Burivalova et al., 2014), reduced-impact logging practices are employed (e.g., Pinard and Putz, 1996; Bicknell et al., 2014), and hunting is limited (e.g., Roopsind et al., 2017).

\section{METHODS}

Blocks of forest with active logging operations in each country were selected at random from strata defined by forest management enterprise (FME) size, soils, elevation, and certification status (i.e., FSC certified or not). The sampled countries (Indonesia, Gabon, Democratic Republic of Congo, Republic of Congo, Suriname, and Mexico) represent a wide range of selective logging intensities, harvesting methods, ecological conditions, and socio-political contexts. In Indonesia field data were collected in recently logged areas with the reduced-impact logging for climate (RIL-C) method described by Griscom et al. $(2014,2019)$, while in other geographies a refined RIL-C protocol was used as described by Ellis P. W. et al. (2019). We deviate from the RIL-C protocol only insofar as we defined accessed areas individually for each country based on delineation of skid trail buffers at the 95th percentile of the distance from stumps of harvested trees to the nearest skid trail; buffers ranged from $9.8 \mathrm{~m}$ in RoC to $32.7 \mathrm{~m}$ in Indonesia (Ellis P. W. et al., 2019; see Figure 1). Basically, to map skid trails in 42 of the 48 logging blocks sampled (one per FME except in Indonesia), field crews equipped with wide-area augmentation system-enabled Garmin GPS receivers mapped an average of $6 \mathrm{~km}$ of skid trails and measured the widths of $5 \mathrm{~km}$ of logging roads (distance between the trunks of standing trees $>10 \mathrm{~cm} \mathrm{DBH}$ ) in recently logged blocks of 38-415 ha (see Ellis P. W. et al., 2019 for further description of field and analytical methods). In the remaining six logging blocks in Indonesia, we collected medium density (mean $=4.5$ points $\mathrm{m}^{-2}$ ), discrete return lidar data from a standard altitude of $650 \mathrm{~m}$ in April 2013 and used those data to map logging impacts in 5,620 ha that included six annual cutting areas encompassing 54 logging blocks in five FMEs following methods described in Ellis et al. (2016) to avoid pseudoreplication, we used mean logging block statistics from each annual cutting area.

The hypothesis that intact forest is farther from the nearest haul road than areas that were accessed by loggers was tested by comparing the means of the Euclidian distances between the closest haul road section and the accessed and intact forest areas in each logging block with a paired $t$-test. Two blocks were excluded due to computational difficulties and additional four were excluded because no haul roads crossed the blocks. Data included in this analysis were from 42 logging blocks in six countries, with six in Indonesia, eight in Mexico, six in Suriname, eight in DRC, eight in Gabon, and six in ROC.

To determine whether loggers avoided steep slopes, we first classified steep forest areas as those with slopes $>40 \%\left(21.8^{\circ}\right)$

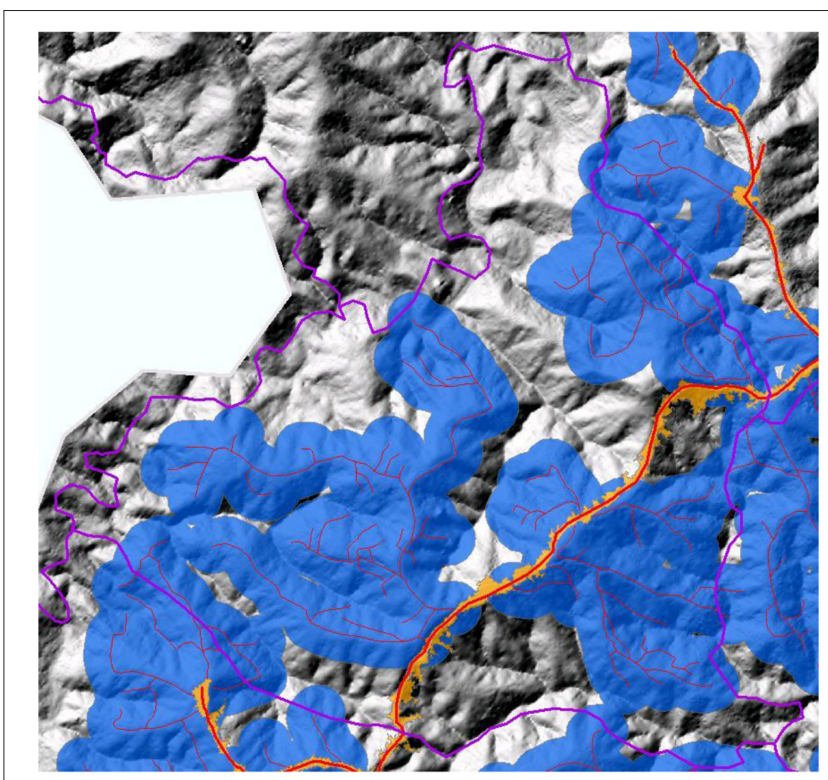

FIGURE 1 | Lidar-delimited (1:10,000) skidding/felling (blue) and haul-road (orange) impact zones in an FME in Kalimantan, Indonesia with purple lines demarcating the logging block boundaries, ridges are indicated by dark shading, valleys with light shading, and the logging road in red (reprinted with permission from Ellis et al., 2016). Note that timber in the area to the northwest was not yet harvested.

based on a 1 arc second $(30 \mathrm{~m})$ digital elevation model (DEM) constructed with SRTM data (USGS, 2004). We then used the proportions of entire logging blocks left intact to generate the expected proportions of intact steep pixels and then compared this expected proportion with the observed values for blocks with $>15 \%$ steep pixels. We used a similar approach to test the hypothesis that loggers avoided riparian areas, which we defined as being within $25 \mathrm{~m}$ of a stream. Of the many ways to identify streams, we employed a basic approach using Esri's Hydrology toolset. First, we located each logged block within a Level 12 HydroSHEDS Basin (Lehner et al., 2008) and used this to bound our analysis area. We identified and filled sinks within each $30 \mathrm{~m}$ DEM, and then used a D8 flow method to compute flow directions. Finally, we calculated the accumulated flow within each watershed and then used the mean flow accummulation for the watershed as the threshold to identify the head of the drainage network (Tang et al., 2001).

All geospatial analyses were conducted in ArcGIS v10. 10.3.1 (ESRI, 2015) and statistical analyses with base packages in R v 3.5.0 ( $R$ Development Core Team, 2016), unless mentioned otherwise.

\section{RESULTS}

Intact forest covered a mean of $69 \%$ (range 20-97\%) of the 48 logged blocks in six tropical countries (Figure 2). When data from all regions are combined, we detected a small but statistically insignificant decrease in the proportion of forest left intact in logged blocks with harvest intensity in the accessed area $\left(\%\right.$ intact $=0.78-0.0026 *$ harvest intensity; $\mathrm{SE}_{\mathrm{b}}=0.0014, \mathrm{df}=$ 


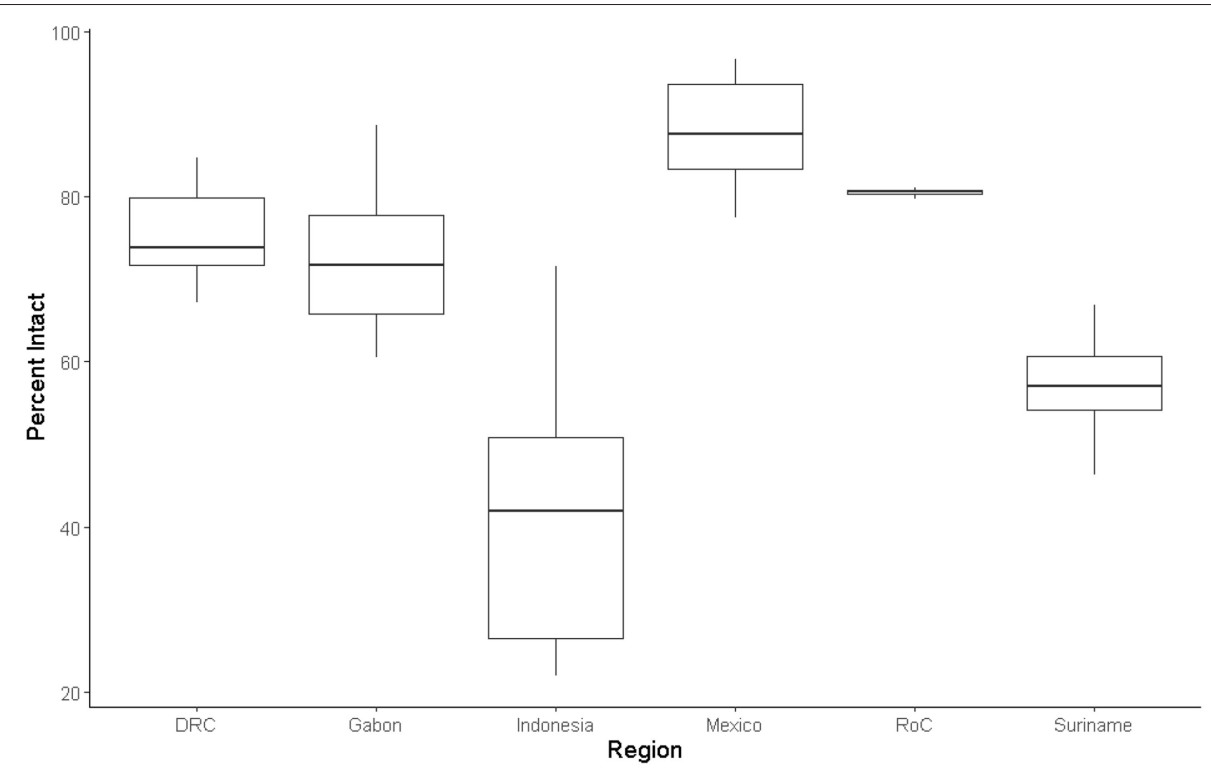

FIGURE 2 | Proportions of intact forest in selectively logged harvest blocks (DRC, Democratic Republic of Congo; RoC, Republic of Congo).

45, $P=0.06$, adjusted $R^{2}=0.055$; Figure 3A). In contrast, if harvest intensities are assumed to represent conditions in entire logging blocks, which is commonly assumed, there was a more marked decrease in intact area with harvest intensity (\% intact = 0.83-0.0109* harvest intensity per cutting block; $\mathrm{SE}_{\mathrm{b}}=0.0015$, $\mathrm{df}=46, P<0.001$, adjusted $R^{2}=0.529$; Figure 3B). In the 42 logging blocks in six countries with road data, as expected, intact areas averaged a larger distance $(289.6 \mathrm{~m}, \mathrm{SD}=25.54 \mathrm{~m})$ from the nearest haul-road than accessed areas $(231 \mathrm{~m}, \mathrm{SD}=20.6 \mathrm{~m} ; t=$ $4.0, P<0.01)$. Distances to haul-roads ranged $64-722 \mathrm{~m}$ for intact areas and $56-662 \mathrm{~m}$ for accessed areas. There was no apparent difference in the proportion of forest left intact in the 12 FSCcertified ( $65 \pm 21 \% \mathrm{SD})$ and the 36 non-certified FMEs $(71 \pm 17 \%$ $\mathrm{SD}, t=0.77, P=0.45$; Figure 4; see supplementary data table for complete results and logging block statistics).

Analyses of the effects of steep slopes and stream buffers on the distribution of logging were limited by the presence of these conditions in the surveyed harvest blocks. Steep areas ( $>40 \%$ slope) covered $<15 \%$ of the logging blocks in Suriname and the Democratic Republic of Congo while there were no streams in the Mexican blocks due to subterranean drainage. Of the 13 logged blocks with their area $>15 \%$ on slopes $>40 \%$, forest was left intact in $76 \%$ of the steep pixels and $60 \%$ of the less steep pixels (SD $=$ 27 and 22\%, respectively; $t=6.8, P<0.001$; Figure 5A). In the 26 blocks with streams, an average of $73 \%$ (S.D. $=24 \%$ ) of pixels $<25 \mathrm{~m}$ from a stream were intact in contrast to $61 \%$ of pixels farther from streams $(S D=26 \% ; t=3.5 ; P<0.001$; Figure 5B).

\section{DISCUSSION}

In the six tropical countries in which we assessed spatial variation in selective logging impacts, more than half of the forest in blocks allocated for logging experienced no direct impacts of timber harvests. This finding indicates that studies that describe the impacts of logging based on data collected only where harvests actually occurred exaggerate those impacts by a factor of two. Depending on the spatial distributions of intact forest in logged landscapes and the permanence of those refugia, opportunities abound for both conservation and silvicultural intensification. Ideally, standing forest should be retained in riparian and other ecologically sensitive areas. Conversely, for both ecological and economic reasons, silvicultural treatments prescribed to increase the stocking and growth of commercial timber should be concentrated near existing roads and on suitable terrain. If appropriate spatial planning regulations were developed and then followed, both economic and ecological benefits could be secured, but tropical forestry has proven itself incredibly resistant to regulatory reform (e.g., Fraser, 2019).

Many factors influenced how much forest was left unscathed by loggers and the locations of the fractions that escaped felling, skidding, and hauling damage. Surprisingly, logging intensity, as expressed in terms of timber volumes harvested from the accessed portions of logging blocks, explained little of the variance in the proportions of intact forest retained. For example, logging refugia were scarce in the intensively logged forests of Indonesia, but were also scarce in Suriname where logging intensities were low. This finding is partially explained by the relatively small sizes of individual trees harvested in Suriname, which meant that for the same volumetic yields, more trees were harvested. To a small but statistically significant extents, loggers avoided areas on steep slopes, near streams, and far from haulroads. Harvesting costs obviously increase with distance but also increase with slope basically due to the need to overcome gravitational forces (Putz et al., 2018). Whether riparian area avoidance was due to regulations, physical constraints on timber extraction, low stocking, or some combination of these factors, 

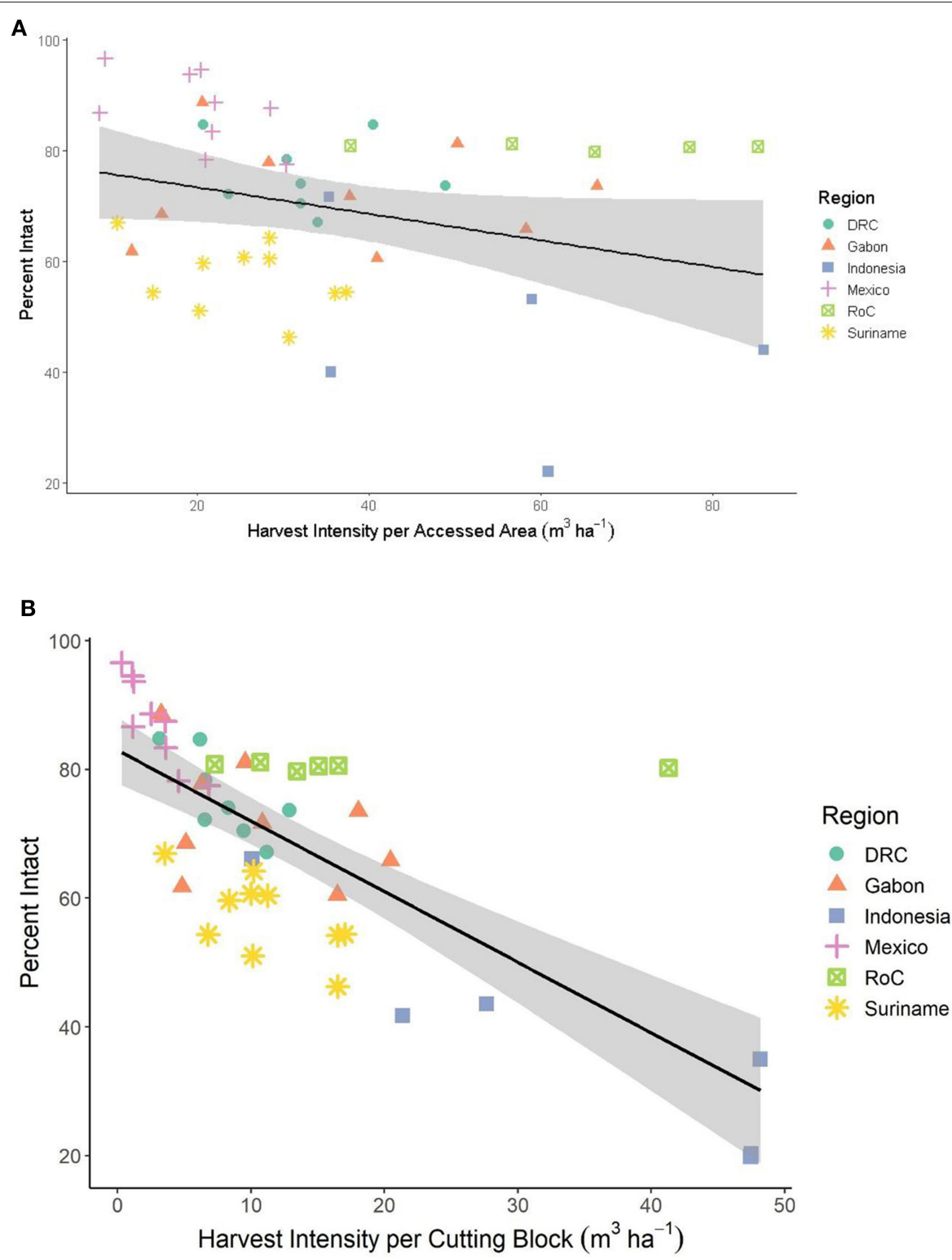

FIGURE 3 | The extents of intact forest (\%) in selectively logged forests as a function of harvest intensities $\left(\mathrm{m}^{3} \mathrm{ha}^{-1}\right)$ in accessed areas (A) and across entire logging (cutting) blocks (B).

the result is clearly environmentally beneficial. We note that in the lidar-sampled FMEs in Indonesia, Ellis et al. (2016) found that above-ground biomass in steep and riparian areas did not differ from elsewhere in the logging blocks, which suggests that timber scarcity was not the predominant cause of these findings.

Given concerns about forest degradation and the fact that selective logging in the tropics is the major cause of that degradation (e.g., Asner et al., 2005; Hosonuma et al., 2012; Pearson et al., 2017), it behooves conservationists to be abundantly clear in their analyses of the impacts of timber harvests and other interventions. Based on the findings presented in this paper, forest degradation analyses (e.g., Vásquez-Grandon et al., 2018) need to consider the spatial patterns of reduced basal area or biomass, loss of species, domination by pioneer species, or lack of regeneration. Clearly, the ecological consequences of a $50 \%$ reduction in biomass are different if that change is spatially uniform than if half the area is clear-cut while the other half remained unscathed. It also matters whether the unscathed portion is a continuous band of riparian forest or small, isolated patches of standing trees in an otherwise deforested landscape. Edge effects also deserve consideration but are likely modest and temporary in selectively logged forests except along the main haul roads, which typically cover $<2 \%$ of logging areas in the tropics (Malcolm and Ray, 2000; Kleinschroth and Healey, 2017). Our analyses demonstrate that the impacts of selective logging are not spatially uniform in the tropics, which is also 


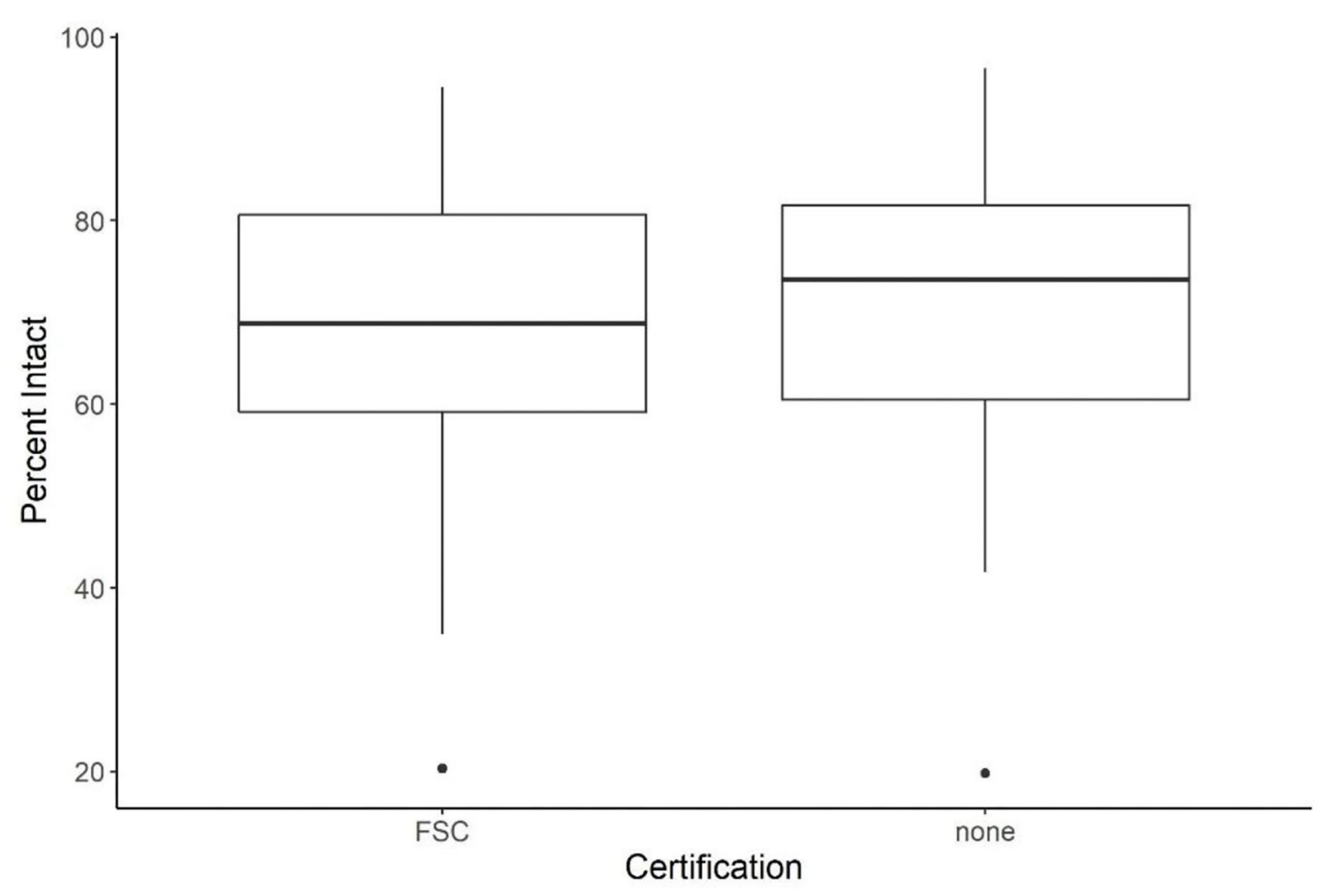

FIGURE 4 | A naïve comparison of the proportions of intact forest in Forest Stewardship Council (FSC; $N=12)$ and non-certified forest management enterprises ( $N=$ 36). Box plot hinges correspond to first and third quartiles, and whiskers extend to highest and lowest values.

apparently the case in similarly treated temperate forests (e.g., Grushecky and Fajvan, 1999).

Comparison of our results with other published measures of logging impacts is challenging due to methodological differences, but the patterns we observed are similar to other reports in the literature. For example, based on field measurements of ground disturbance by selective logging in South America reported for 17 plots in six different published studies, Feldpausch et al. (2005) reported that $46-88 \%$ of the forest was not affected directly by logging. Those same authors reported that intact forest area decreased with logging intensity and was much smaller for conventional logging than RIL. In a more recent study of a forest subjected to RIL in Belize at a block-wide intensity of $2.9 \mathrm{~m}^{3} \mathrm{ha}^{-1}$ (2.7 trees ha ${ }^{-1}$ ), Arevalo et al. (2016) reported that $93 \%$ of the 350-ha harvest block experienced no direct impacts of logging. That value is much higher than the global average of $69 \%$ intact reported here, but is similar to the $77-97 \%$ intact forest found in logging blocks in Mexico where harvest intensities were also low (0.24-3.15 trees/ha). Similarly, in a pantropical review of the literature on logging roads, Kleinschroth and Healey (2017) reported a median impact of $1.7 \%$ of the ground surface. Studies based on remote sensing, especially those that employed canopypenetrating lidar and wall-to-wall sampling of logged blocks, often report considerably higher proportions of intact forest than field studies (e.g., Ellis et al., 2016). Despite the opportunities for lidar to detect accessed areas accurately (Melendy et al., 2018), larger scale studies using canopy-penetrating lidar have yet to reveal the spatial patterns of intactness in landscapes designated for logging beyond the scale of individual harvest blocks, which could have large implications for meta-population dynamics.

Considerations of the impacts of selective logging in the tropics need to reflect its tremendous spatial variation at all scales. If large portions of logged areas are not directly affected by logging, any data collected on or adjacent to roads, skid trails, or felling gaps (i.e., in the impact zones) needs to be adjusted accordingly. Failure to adjust the results to account for the areas not directly affected clearly exaggerates the impacts of logging. For example, the much- cited study by Thiollay (1997) on the influence of selective logging on birds in French Guiana was based on point counts centered on skid trails and in logging gaps. More recently, Blonder et al. (2018) reported substantially higher temperatures in moderately and heavily logged forests than in old growth, but the two logged hectare plots lost 53 and 86\% of their biomass, respectively. It would be dangerous to extend these results to other selectively logged tropical forests that lose, on average, only $11 \%$ of their biomass (Ellis P. W. et al., 2019).

Maximizing intact forest in areas designated for logging might, from a landscape-level environmental perspective, be counter-productive especially if by so doing, timber yields decline. Instead, we advocate first of all for scrupulous use of RIL practices and for yield maintenance in designated portions of the logging landscape that are ecologically and economically 
A

Steep Slopes (>40\%)

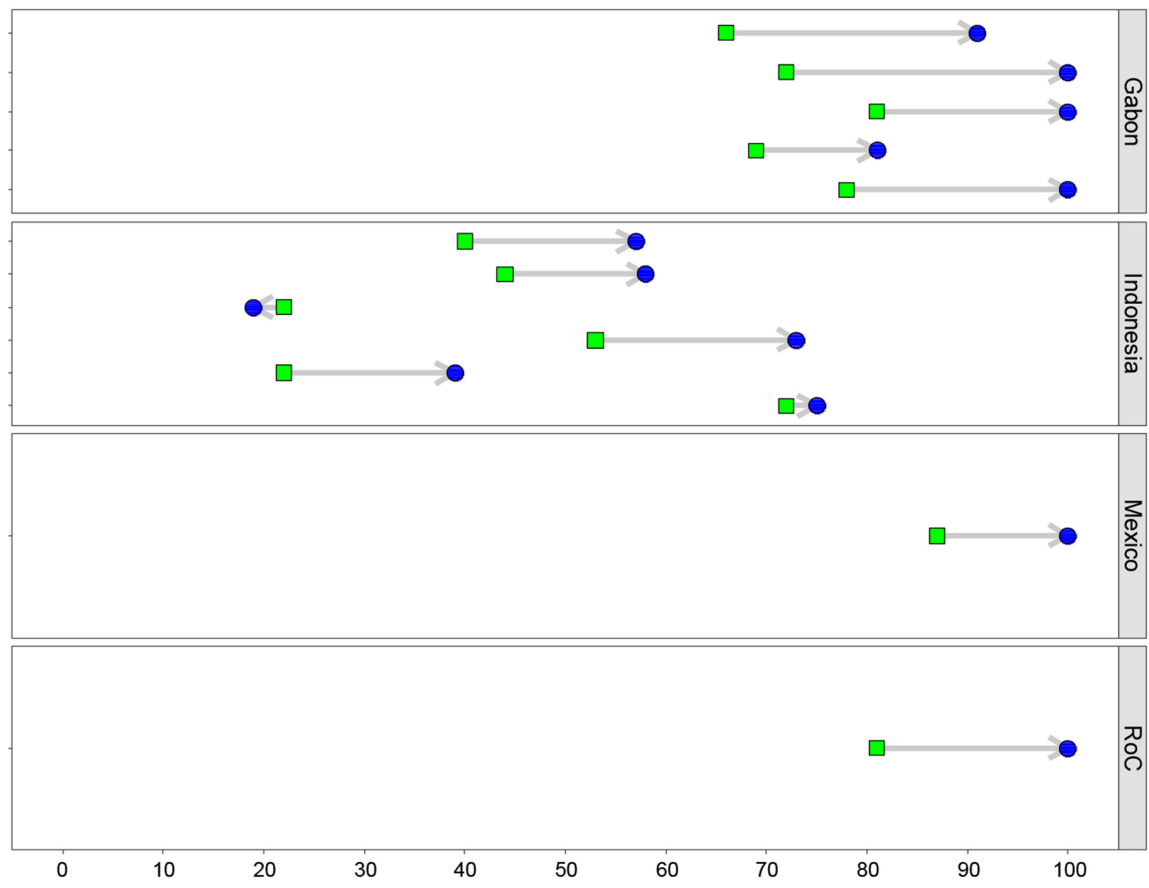

Percent Intact

B

Riparian Areas

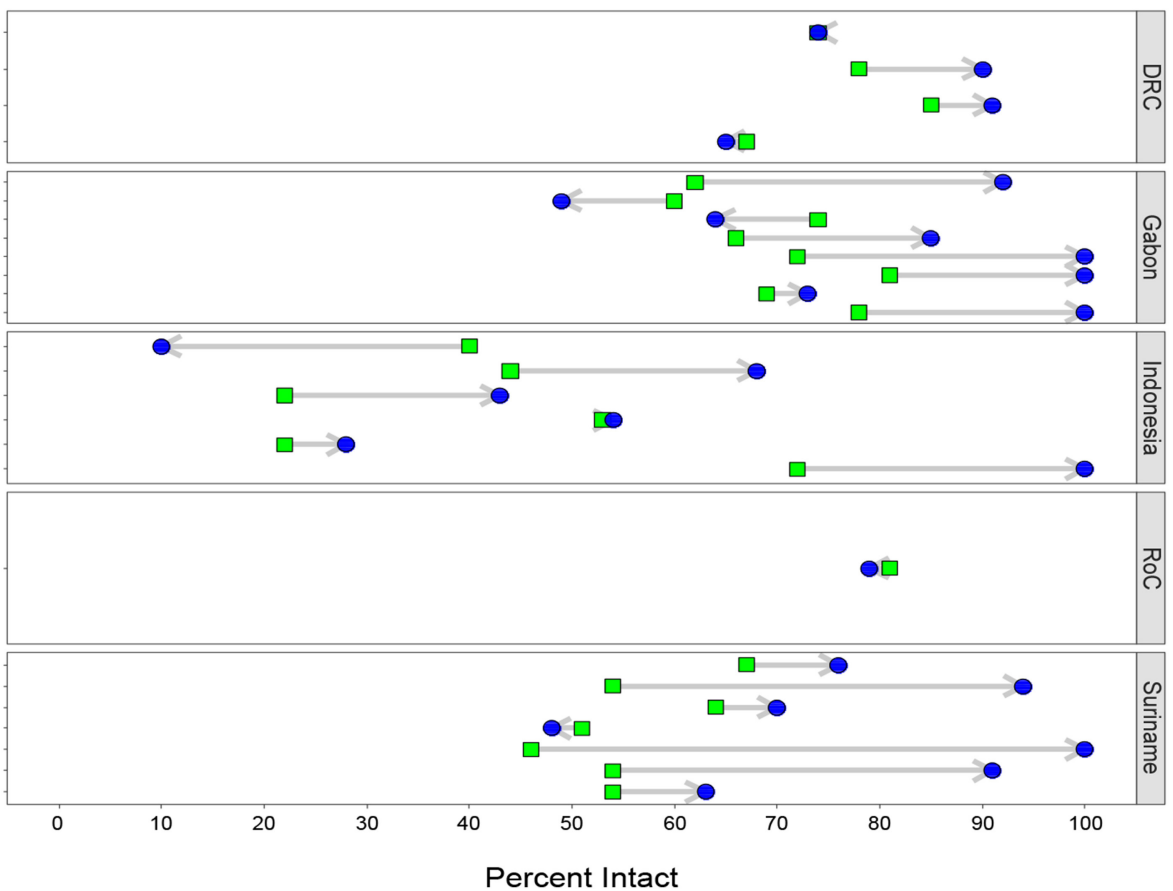

FIGURE 5 | Percentages of $30 \mathrm{~m}$ pixels in logged blocks left intact by loggers on (A) steep slopes (>40\%) and (B) $<25 \mathrm{~m}$ of permanent streams. Green squares show the percent of intact forest in entire logged blocks, blue dots show percent intact on steep slopes and in riparian zones, and gray arrows represent the residual effect size. 
appropriate. We also endorse at least gentle silvicultural intensification with interventions designed to increase growth and yield, such as cutting lianas on future crop trees (e.g., Putz and Romero, 2015; Mills et al., 2019). In addition to accessibility, site capability, and environmental or cultural constraints, spatial planning of management in logging landscapes in the tropics should also consider adjacency, connectivity, and patch size (e.g., Llorente et al., 2017).

Improvements in tropical forest management require better spatial planning, but such plans, if properly implemented, might reduce the area of intact forest in logged blocks unless accompanied by clear demarcation and better protection of ecologically sensitive areas. Better planning of logging operations might explain why our naïve comparison on FSC certified and non-certified FMEs did not differ in amounts of intact forest retained. Indeed, one of the benefits of proper planning and implementation of RIL operations is that fewer trees and logs are missed by harvest crews (Holmes et al., 2002). Our results also show that loggers already avoid steep areas and riparian zones to some extent, but they also seem to skip patches of forest with standing commercial timber apparently because they are unaware of its existence, despite their preparation of government-required stand maps. The reliability and actual use of those maps in Suriname (Zalman et al., 2019) may explain the scarcity of intact forest in the relatively lightly logged harvest blocks in that country (Figure 2). Alternatively, perhaps trees were left standing in patches of intact forest after loggers reached the volumetric quotas set by government or the industries they supply.

RIL is promoted as leakage-free insofar as yield reductions are not required, and as more cost-effective than conventional logging, despite the mixed support for these claims in the literature (Medjibe and Putz, 2012; Sasaki et al., 2016). The claim of being leakage-free is admittedly not supported when scrupulous adherence to RIL guidelines results in no logging on steep slopes, in riparian areas, in inaccessible enclaves, and during wet weather (Healey et al., 2000). Logic supports the claim that RIL is more profitable than conventional logging, but the data are far from consistent. The model studies on this topic, both conducted in Amazonian Brazil by Barreto et al. (1998) and Holmes et al. (2002), reported that RIL was, respectively, 35 and $18 \%$ more profitable than conventional logging. The principal financial benefits derived from worker training, harvest planning, and close supervision were from higher timber recovery in RIL areas. Directional felling by trained workers toward pre-planned skid trails coupled with better bucking and less felling damage to commercial logs should all also result in more efficient and less costly harvests, but this assumption is not consistently supported by research (Medjibe and Putz, 2012). Given the deficiencies in the experimental designs of many cost-benefit analyses of RIL and the variety of conditions under which selective logging is carried out in the tropics, the financial consequences of adoption of improved logging practices remain unclear. What is made clear by the lack of adoption of RIL (e.g., Ellis P. W. et al., 2019) is that the decision-makers in tropical forestry operations, be they concession owners, crew bosses, or chain saw operators, clearly do not recognize the financial benefits of RIL. An obvious need is for more and better research that tracks the costs and benefits by specific operation (e.g., tree felling, log skidding, and worker training) and from the perspectives of the various relevant stakeholders (e.g., chainsaw operators, crew bosses, and concession owners; Putz and Romero, 2012). Alternatively, given the existence of an accurate and inexpensive way to monitor logging impacts with the RIL-C protocol (e.g., Ellis P. W. et al., 2019), where there are reliable regulatory authorities, FMEs could be rewarded for demonstrated improvements in their forest management practices relative to established baselines.

\section{RECOMMENDATIONS}

The environmental benefits of the intact forest in logged landscapes would be greatly enhanced by spatial planning with enforcement of restrictions on access to sensitive habitats. If the observed proportions of selectively logged forest were left intact near streams and on steep slopes, the deleterious environmental impacts of logging would be greatly diminished (Griscom et al., 2019). In addition to the hydrological benefits, protection of riparian corridors would enhance connectivity for wildlife. Any reductions in timber yields could be easily compensated for with silvicultural treatments in accessible stands (e.g., Ruslandi et al., 2017). Enforcement of spatial planning regulations could be enhanced if governmental and certification body auditors included comprehensive GPS tracks in their reports on inspections of logging locations and practices.

To reduce the deleterious environmental impacts of selective logging in steep areas, we endorse long-line cable yarding with modified excavators (e.g., LogFishers: http://www.logfisher.com/ contact.html). Such machines move easily along ridge-top roads so that almost every log follows a different path of up to $200 \mathrm{~m}$ upslope. Even in the absence of data, we are confident that this approach, at least compared to cutting switchbacks with bulldozers, results in reductions in soil damage, carbon emissions, and costs. We advocate this approach to cable yarding in full recognition of the massive but little documented environmental destruction caused by unregulated high-lead cable yarding in Malaysian Borneo and the Philippines during the 1970s and 1980s (reviewed by Ewel and Conde, 1981). While it would be environmentally preferable to not log steep slopes, few countries have such prohibitions (Putz et al., 2018). Furthermore, if slope restrictions were enacted and enforced, yields from the increasingly steep lands being allocated for logging would decline and risks of activity-shifting leakage (i.e., loggers go elsewhere for timber) would increase.

Data limitations make it difficult to assess the permanence of the intact forests in logged landscapes. We were surprised to learn the extent to which governmental agencies ultimately responsible for the forest and FME managers both lacked reliable records of the locations of previous episodes of timber extraction. Be that as it may, if the intact patches retained through the first harvest are logged after only 25-30 years, the reprieves are not durable. Perhaps worse, if hunters travel the logging roads to access intact areas and wipe out wildlife, that dimension of intactness will disappear. Furthermore, just as species differ in the degree to which their biology is disrupted by selective logging, the impacts of that intervention are not all immediate-some increase in 
response to elevated post-logging tree mortality rates while others decrease as forest recovers.

The emphasis of many environmental scientists on describing in ever-increasing detail the problems associated with selective logging in the tropics needs to shift toward finding solutions to those problems. Researchers and environmental advocates need to accept that, at least in much of the remaining tropical forest of the world, as long as there is merchantable timber to be harvested, logging is likely. Whether that logging is carried out by private forest owners, entrepreneurial rural communities and indigenous groups, or the employees of large corporations, there will be impacts. Understanding these impacts is essential, but given that many are obvious already well described, attention should be directed toward finding financially viable and ecologically sound ways to manage tropical forests sustainably. To this end, more full-fledged silviculturalists, mensurationists, forest engineers, and forest economists are essential, but well-trained ecologists can also re-train in those more applied disciplines. More to the main point of this study, improved spatial planning of logging and other silvicultural interventions will help increase the sustainability of natural forest management in the tropics.

\section{AUTHOR CONTRIBUTIONS}

The study was designed by FP and PE based on data provided by BG, EE, JZ, and PU. TB, TG, and PE did much of the data

\section{REFERENCES}

Arevalo, B., Valladarez, J., Muschamp, S., Kay, E., Finkral, A., Roopsind, A., et al. (2016). Effects of reduced-impact selective logging on palm regeneration in Belize. For. Ecol. Manage. 369, 155-160. doi: 10.1016/j.foreco.2016.03.040

Arroyo-Rodríguez, V., Pineda, E., Escobar, F., and Benítez-Malvido, J. (2009). Value of small patches in the conservation of plant-species diversity in highly fragmented rainforest. Con. Biol. 23, 729-739. doi: 10.1111/j.1523-1739.2008.01120.x

Asner, G. P., Knapp, D. E., Broadbent, E. N., Oliveira, P. J., Keller, M., and Silva, J. N. (2005). Selective logging in the Brazilian Amazon. Science 310, 480-482. doi: 10.1126/science.1118051

Barreto, P., Amaral, P., Vidal, E., and Uhl, C. (1998). Costs and benefits of forest management for timber production in eastern Amazonia. For. Ecol. Manage. 108, 9-26. doi: 10.1016/S0378-1127(97)00251-X

Bicknell, J. E., Struebig, M. J., Edwards, D. P., and Davies, Z. G. (2014). Improved timber harvest techniques maintain biodiversity in tropical forests. Curr. Biol. 24, R1119-R1120. doi: 10.1016/j.cub.2014.10.067

Blonder, B., Both, S., Coomes, D. A., Elias, D., Jucker, T., Kvasnica, J. et al. (2018). Extreme and highly heterogeneous microclimates in selectively logged tropical forests. Fronti. For. Glob. Change 1:5. doi: 10.3389/ffgc.2018.00005

Burivalova, Z., Sekercioglu, Ç. H., and Koh, L. P. (2014). Thresholds of logging intensity to maintain tropical forest biodiversity. Curr. Biol. 24, 1893-1898. doi: 10.1016/j.cub.2014.06.065

Edwards, D. P., Gilroy, J. J., Woodcock, P., Edwards, F. A., Larsen, T. H., Andrews, D. J., et al. (2014). Land-sharing versus land-sparing logging; reconciling timber extraction with biodiversity conservation. Glob. Change Biol. 20, 183-191. doi: $10.1111 /$ gcb.12353

Ellis, E. A., Armenta Montero, S., Hernández Gómez, I. U., Romero Montero, J. A., and Ellis, P., Gopalakrishna, Putz, F. E., et al. (2019). Reduced-impact logging practices reduce forest disturbance and carbon emissions in community managed forests on the Yucatán Peninsula, Mexico. For. Ecol. Manage. 437, 396-410. doi: 10.1016/j.foreco.2019.01.040 analysis, with input from R and AR. All authors commented on earlier versions of this article.

\section{FUNDING}

Support for the field work that yielded the data on which this analysis was based was provided by the Doris Duke Charitable Foundation and International Paper through The Nature Conservancy.

\section{ACKNOWLEDGMENTS}

We thank the other researchers and field staff involved in collecting the data used in this analysis. A. Shenkin provided helpful advice on the statistical analyses and C. Romero, J. Halperin, and S. Machado provided useful comments on earlier versions of this article.

\section{SUPPLEMENTARY MATERIAL}

The Supplementary Material for this article can be found online at: https://www.frontiersin.org/articles/10.3389/ffgc.2019. 00030/full\#supplementary-material

Supplementary Table 1 | Summary statistics for the logged blocks assessed in this study.

Ellis, P. W., Gopalakrishna, T., Goodman, R. C., Roopsind, A., Briscom, B. W., Umunay, P. M., et al. (2019). Climate-effective reduced-impact logging (RIL-C) can halve selective logging emissions from Tropical forests. For. Ecol. Manage. 438, 255-260. doi: 10.1016/j.foreco.2019.02.004

Ellis, P. W., Griscom, B. W., Walker, W., Gonçalves, F., and Cormier, T., (2016). Mapping selective logging impacts in Borneo with GPS and airborne lidar. For. Ecol. Manage. 365, 184-196. doi: 10.1016/j.foreco.2016.01.020

ESRI (2015). ArcGIS Desktop: Release 10.3.1. Redlands, CA: Environmental Systems Research Institute.

Ewel, J., and Conde, L. F. (1981). Potential Ecological Impact of Increased Intensity of Tropical Forest Utilization. BIOTROP SEAMEO Special Publication 11.

Ewers, R. M., and Banks-Leite, C. (2013). Fragmentation impairs the microclimate buffering effect of tropical forests. PLoS ONE 8:e58093. doi: 10.1371/journal.pone.0058093

Feldpausch, T. R., Jirka, S., Passos, C. A. M., Jasper, F., and Riha, S. J. (2005). When big trees fall: damage and carbon exprot by reduced impact logging in southern Amazonia. For. Ecol. Manage. 219, 199-215. doi: 10.1016/j.foreco.2005.09.003

Fraser, A. (2019). Achieving the Sustainable Management of Forests. Cham: Springer. doi: 10.1007/978-3-030-15839-2

Griscom, B., Ellis, P., and Putz, F. E. (2014). Carbon emissions performance of commercial logging in East Kalimantan, Indonesia. Glob. Chang. Biol. 20, 923-937. doi: 10.1111/gcb.12386

Griscom, B. W., Ellis, P. W., Burvalova, Z., Halperin, J., Marthinus, D., Runting, R. K., et al. (2019). Reduced-impact logging in Borneo to minimize carbon emissions and impacts on sensitive habitats while maintaining timber yields. For. Ecol. Manage. 438, 176-185. doi: 10.1016/j.foreco.2019.02.025

Griscom, B. W., Goodman, R. C., Burivalova, Z., and Putz, F. E. (2018). Carbon and biodiversity impacts of intensive versus extensive tropical forestry. Conserv. Lett. 11, 1-9. doi: 10.1111/conl.12362

Grushecky, S. T., and Fajvan, M. A. (1999). Comparison of hardwood stand structure after partial harvesting using intensity canopy maps and geostatistical techniques. For. Ecol. Manage. 114, 421-432. doi: 10.1016/S0378-1127(98)00372-7 
Healey, J. R., Price, C., and Tay, J. (2000). The cost of carbon retention by reduced impact logging. For. Ecol. Manage. 139, 237-255. doi: 10.1016/S0378-1127(00)00385-6

Holmes, T. P., Blate, G. M., Zweede, F. C., Perrera, R., Baretto, P., Boltz, F., et al. (2002). Financial and ecological indicators of reduced-impact logging performance in the eastern Amazon. For. Ecol. Manage. 163, 93-110. doi: 10.1016/S0378-1127(01)00530-8

Hosonuma, N., Herold, M., De Sy, V., De Fries, R. S., Brockhaus, M., Verchot, L., et al. (2012). An assessment of deforestation and forest degradation drivers in developing countries. Environ. Res. Lett. 7:044009. doi: 10.1088/1748-9326/7/4/044009

Kleinschroth, F., and Healey, J. R. (2017). Impacts of logging roads on tropical forests. Biotropica 49, 620-635. doi: 10.1111/btp.12462

Kolden, C. A., Bleeker, T. M., Smith, A. M. S., Poulos, H. M., and Camp, A. E. (2017). Fire effects on historical wildfire refugia in contemporary wildfires. Forests 8:400. doi: 10.3390/f8100400

Lehner, B., Verdin, K., and Jarvis, A. (2008). New global hydrography derived from spaceborne elevation data. Eos Trans. AGU 89, 93-94. doi: 10.1029/2008EO100001

Llorente, I. D. P., Hoganson, H. M., Carson, M. T., and Windmuller-Campione, M. (2017). Recognizing spatial considerations in forest management planning. Curr. Forestry Rep. 3, 308-316. doi: 10.1007/s40725-017-0068-x

Malcolm, J. R., and Ray, J. C. (2000). Influence of timber extraction routes on Central African small mammal communities, forest structure, and tree diversity. Con. Bio. 14, 1623-1638. doi: 10.1046/j.1523-1739.2000.99070.x

Medjibe, V. P., and Putz, F. E. (2012). Cost comparisons of reducedimpact and conventional logging in the tropics. J. For. Econ. 18, 242-256. doi: 10.1016/j.jfe.2012.05.001

Medjibe, V. P., Starkey, M., Ndouna, A. A., Memiaghe, H. R., and Putz, F. E. (2011). Impacts of timber extraction on above-ground forest biomass on Monts de Cristal in Gabon. Forest Ecol. Manage. 262, 1799-1806. doi: 10.1016/j.foreco.2011.07.014

Melendy, L., Hagen, S. C., Sullivan, F. B., Pearson, T. R. H., Walker, S. M., Ellis, P., et al. (2018). Automated method for measuring the extent of selective logging damage with airborne LiDAR data. ISPRS J. Photogramm. Remote Sens. 139, 228-240. doi: 10.1016/j.isprsjprs.2018.02.022

Mills, D. J., Andreu, M. G., Bohlman, S. A., and Putz, F. E. (2019). Liberation of future crop trees from lianas in Belize: completeness, costs, and timber-yield benefits. For. Ecol. Manage. 439, 97-104. doi: 10.1016/j.foreco.2019.02.023

Pearson, T. R. H., Brown, S., Murray, L., and Sidman, G. (2017). Greenhouse gas emissions from tropical forest degradation: an underestimated source. Carbon Balance Manag. 12:113. doi: 10.1186/s13021-017-0072-2

Pfeifer, M., Kor, L., Nilus, R., Turner, E., Cusack, J., Lysenko, I., et al. (2016). Mapping the structure of Borneo's tropical forests across a degradation gradient. Rem. Sens. Environ. 176, 84-97doi: 10.1016/j.rse.2016.01.014

Phalan, B., Onial, M., Balmford, A., and Green, R. E. (2011). Reconciling food production and biodiversity conservation: land sharing and land sparing compared. Science 333, 1289-1291. doi: 10.1126/science.1208742

Pinard, M. A., and Putz, F. E. (1996). Retaining forest biomass by reducing logging damage. Biotropica 28, 278-295. doi: 10.2307/2389193

Potapov, P., Hansen, M. C., Laestadius, L., Turubanova, S., Yaroshenko, A., Thies, C., et al. (2017). The last frontiers of wilderness: tracking loss of intact forest landscapes from 2000 to 2013. Sci. Adv. 3:e1600821. doi: 10.1126/sciadv.1600821

Potapov, P., Yaroshenko, A., Turubanova, S., Dubinin, M., Laestadius, L., Thies, C., et al. (2008). Mapping the world's intact forest landscapes by remote sensing. Ecol. Soc. 13:51. doi: 10.5751/ES-02670-130251

Putz, F. E., Blate, G. M., Redford, K. H., Fimbel, R., and Robinson, J. G. (2001). Biodiversity conservation in the context of tropical forest management. Conserv. Biol. 15, 7-20. doi: 10.1046/j.1523-1739.2001.00018.x

Putz, F. E., and Romero, C. (2012). Helping curb tropical forest degradation by linking REDD+ with other conservation interventions: a view from the forest. Curr. Opin. Environ. Sustain. 4, 670-677. doi: 10.1016/j.cosust.2012.10.003

Putz, F. E., and Romero, C. (2015). Futures of tropical production forests. Center Int. For. Res. Occasional Paper 143, 1-39. doi: 10.17528/cifor/005766

Putz, F. E., Ruslandi, Ellis, P. W., and Griscom, B, W. (2018). Topographic restrictions on land-use practices: consequences of different pixel sizes and data sources for natural forest management in the tropics. Forest Ecol. Manage. 422, 108-113. doi: 10.1016/j.foreco.2018.04.001
Putz, F. E., Zuidema, P. A., Synnott, T., Peña-Claros, M., Pinard, M. A., Sheil, D. et al. (2012). Sustaining conservation values in selectively logged tropical forests: the attained and the attainable. Conservation Conserv. Letters Lett. 5: , 296-303. doi: 10.1111/j.1755-263X.2012.00242.x

R Development Core Team (2016). R: A Language and Environment for Statistical Computing.

Riutta, T., Malhi, Y., Khoon, K. L., Marthews, T. R., Huasco, W. H., Khoo, M., et al. (2018). Logging disturbance shifts net primary productivity and its allocation in Bornean tropical forests. Glob. Change Biol. 24, 2913-2928. doi: $10.1111 /$ gcb. 14068

Romero, C., Sills, E. O., Guariguata, M. R., Cerutti, P. O., Lescuyer, G. L., and Putz, F. E. (2017). Evaluation of the impacts of FSC certification on natural forest management in the tropics: a rigorous approach to assessment of a complex conservation intervention. Int. For. Rev. 19, 1-14.

Roopsind, A., Caughlin, T., Sambhu, H., Fragosa, J. M., and Putz, F. E. (2017). Logging and indigenous hunting impacts on persistence of large Neotropical animals. Biotropica 49, 565-575. doi: 10.1111/btp.12446

Runting, R. K., Ruslandi, Griscom, B., Struebig, M. J., Satar, M., Meijaard, E., et al. (2019). Larger gains from improved management over sparing-sharing for tropical forests. Nat. Sustain. 2, 53-61. doi: 10.1038/s41893-018-0203-0

Ruslandi, Cropper, W., and Putz, F. E. (2017). Effects of silvicultural intensification on timber yields, carbon dynamics, and tree species composition in a dipterocarp forest in Kalimantan, Indonesia: an individual-tree-based model simulation. For. Ecol. Manage. 390, 104-118. doi: 10.1016/j.foreco.2017.01.019

Sasaki, N., Asner, G. P., Pan, Y., Knorr, W., Durst, P. B., Ma, H. O., et al. (2016). Sustainable management of tropical forests can reduce carbon emissions and stabilize timber production. Front. Environ. Sci. 4, 1-13:50. doi: $10.3389 /$ fenvs.2016.00050

Senior, R. A., Hill, J. K., Benedick, S., and Edwards, D. P. (2017). Tropical forests are thermally buffered despite intensive selective logging. Glob. Change Biol. 24, 1267-1278. doi: 10.1111/gcb.13914

Sist, P., and Nguyen-Thé, N. (2002). Logging damage and the subsequent dynamics of a dipterocarp forest in East Kalimantan (1990-1996). For. Ecol. Manage. 165, 85-103. doi: 10.1016/S0378-1127(01)00649-1

Sist, P., Nolan, T., Bertault, J.-G., and Dykstra, D. (1998). Harvesting intensity versus sustainability in Indonesia. For. Ecol. Manage. 108, 251-260.

Tang, G., Yang-he, H., Strobl, J., and Wang-qing, L. (2001). The impact of resolution on the accuracy of hydrologic data derived from DEMs. J. Geogr. Sci. 11, 393-401. doi: 10.1007/BF02837966

Thiollay, J. M. (1997). Disturbance, selective logging and bird diversity: a Neotropical forest study. Biodivers. Conserv. 6, 1155-1173.

Thompson, I. D., Guariguata, M. R., Okabe, K., Bahamondez, C., Nasi, R., Heymell, V., et al. (2013). An operational framework for defining and monitoring forest degradation. Ecol. Soc. 18:20. Available online at: http://www. ecologyandsociety.org/vol18/iss2/art20

Turner, I. M., and Corlett, R. T. (1996). The conservation value of small, isolated fragments of lowland tropical rain forest. TREE 11, 330-333. doi: 10.1016/0169-5347(96)10046-X

USGS (2004) USGS. Available online at: https://www.usgs.gov/centers/eros/ science/usgs-eros-archive-digital-elevation-shuttle-radar-topographymission-srtm-1-arc?qt-science_center_objects=0\#qt-science_center_objects

Vásquez-Grandon, A., Donoso, P. J., and Gerding, V. (2018). Forest degradation: when is a forest degraded? Forests 9:726. doi: 10.3390/f91 10726

Zalman, J., Roopsind, A., Ellis, P. W., and Crabbe, S. (2019). Carbon emissions from selective logging in Suriname. For. Ecol. Manage. 439, 9-17. doi: 10.1016/j.foreco.2019.02.026

Conflict of Interest Statement: The authors declare that the research was conducted in the absence of any commercial or financial relationships that could be construed as a potential conflict of interest.

Copyright (c) 2019 Putz, Baker, Griscom, Gopalakrishna, Roopsind, Umunay, Zalman, Ellis, Ruslandi and Ellis. This is an open-access article distributed under the terms of the Creative Commons Attribution License (CC BY). The use, distribution or reproduction in other forums is permitted, provided the original author $(s)$ and the copyright owner(s) are credited and that the original publication in this journal is cited, in accordance with accepted academic practice. No use, distribution or reproduction is permitted which does not comply with these terms. 